\title{
Paddy rice stored under hermetic conditions: The effect of relative humidity, temperature and storage time in suppressing Sitophilus zeamais and impact on rice quality
}

\author{
Maria Otilia Carvalho a, b, *, Patrícia Fradinho a, M. João Martins a, c, Ana Magro a, \\ Anabela Raymundo ${ }^{\mathrm{a}, \mathrm{b}}$, Isabel de Sousa ${ }^{\mathrm{a}, \mathrm{b}}$ \\ a Universidade de Lisboa, Instituto Superior de Agronomia, Tapada da Ajuda, 1349-017, Lisboa, Portugal \\ ${ }^{\mathrm{b}}$ LEAF-Linking Landscape, Environment, Agriculture and Food, Tapada da Ajuda, 1349-017, Lisboa, Portugal \\ ${ }^{\text {c } C E F-F o r e s t ~ R e s e a r c h ~ C e n t r e, ~ T a p a d a ~ d a ~ A j u d a, ~ 1349-017, ~ L i s b o a, ~ P o r t u g a l ~}$
}

\section{A R T I C L E I N F O}

\section{Article history:}

Received 8 November 2017

Received in revised form

3 October 2018

Accepted 8 November 2018

\section{Keywords:}

Paddy

Hermetic storage

Sitophilus zeamais

Rheology

\begin{abstract}
A B S T R A C T
The aim of this study was to analyse the effect of relative humidity in suppressing Sitophilus zeamais, in paddy rice stored under hermetic conditions, during four and seven months, at different average temperatures, as well as the impact on rice quality.

Hermetic bags, GrainPro ${ }^{\circledR}$ SuperGrainbag $\left.{ }^{(}\right)$Farm $^{\mathrm{TM}}$, were used to store two rice varieties under three different relative humidities: $67 \%, 75 \%$ and $85 \% \mathrm{RH}$, and average temperatures of $14{ }^{\circ} \mathrm{C}, 17^{\circ} \mathrm{C}$ and $24{ }^{\circ} \mathrm{C}$, both monitored by Hobo ${ }^{\circledR}$ Data loggers, with the probe placed inside the bags. CheckpointII Portable $\mathrm{O}_{2}$ and $\mathrm{CO}_{2}$ Gas Analyzer was used to assess gas contents on the top and bottom of each bag. At the end of the trials, paddy samples were collected to estimate water activity $\left(a_{w}\right)$. The rheology behaviour of rice pastes prepared with race flour obtained from the different treatments was also evaluated, using a controlled stress rheometer.

The results showed that the response of the stored-product insects changes with environmental conditions, $\mathrm{O}_{2}$ and $\mathrm{CO}_{2}$ contents. Other parameters were considered; $\mathrm{a}_{\mathrm{w}}$ increased with relative humidity and temperature, but decreased with storage time. The relative humidity played an important role, together with the increase of temperature, in suppressing insect populations. A modified atmosphere was naturally produced inside the hermetic bag, under $85 \% \mathrm{RH}$, with low $\mathrm{O}_{2}$ and high $\mathrm{CO}_{2}$ contents, at different average temperatures, $14^{\circ} \mathrm{C}$ and $17^{\circ} \mathrm{C}$. These results demonstrated that $\mathrm{S}$. zeamais can survive, but has no progeny. Under the same conditions, but at the higher average temperature of $24^{\circ} \mathrm{C}$, S. zeamais attained $100 \%$ mortality before producing progeny.

The increase on respiration rate, registered by $\mathrm{CO}_{2}$ increase and $\mathrm{O}_{2}$ decrease, for higher $\mathrm{RH}$ values, reduced the viscoelastic functions and changed the starch gelatinization point of Indica and Japonica rice.

The results obtained showed that storing paddy hermetically, at low relative humidity, did not change atmospheric content and maintained the viscoelastic functions of the rice pastes.
\end{abstract}

(C) 2018 Elsevier Ltd. All rights reserved.

\section{Introduction}

Humans have known, for at least 2500 years that hermetic storage can be used for the preservation of dry products (Adler et al., 2000). The principle of hermetic storage is to avoid any interactions with the surrounding environment. This is considered as

\footnotetext{
* Corresponding author. Universidade de Lisboa, Instituto Superior de Agronomia, Tapada da Ajuda, 1349-017, Lisboa, Portugal.

E-mail address: motiliac@isa.ulisboa.pt (M.O. Carvalho).
}

a type of modified atmospheres (MA), because this method takes the advantage of the gases naturally produced by the respiratory metabolism of the insects, fungi and commodity itself, generating a MA by reducing $\mathrm{O}_{2}$ and increasing $\mathrm{CO}_{2}$ concentrations, and consequently preventing insects and fungi development (Navarro, 2006). The storage life of food products is considerably extended by MA surrounding the food, which reduces also the respiration rate of the food products. (Jayas and Jeyamkondan, 2002). This is one of the natural food preservation methods that maintains the quality of food products in addition to extending the storage life. 
This method has been extensively used on grain namely on rice preservation (Navarro, 1978; Moreno-Martinez et al., 2000; Jayas and Jeyamkondan, 2002; Conyers and Bell, 2007). The exposure time needed to control the insect populations and to protect the grain depends on the degree of infestation, environmental conditions and storage time. The rate of atmosphere modification also depends on environmental conditions and degree of infestation.

Portugal is the largest consumer of rice per capita ( $16 \mathrm{~kg}$ per capita) in Europe (average $8 \mathrm{~kg}$ ), and consequently a large number of farmers and industries are associated with rice production, transportation, storage and processing. In Portugal, rice is a seasonal crop and storage is very important for year round availability. Planting of rice takes place in April and harvest is near the end of August (Carvalho et al., 2012b). After harvesting, drying is the most critical operation. Delays on drying, incomplete drying or ineffective drying might reduce grain quality and result in considerable economic losses (Sinha et al., 2010). The flux of the grain can surpass the drying capacity resulting in difficulties to dry the cereal properly. In some regions of Portugal, rice is stored as paddy on farm horizontal warehouses or vertical silos, until the end of winter. The major pest of stored rice in Portugal is the maize weevil, Sitophilus zeamais Motschulsky. Applications of hermetic storage and modified atmospheres to preserve the quality and flavour of rice during storage can be promising, safe and environmental friendly.

The aim of this study was to evaluate the relationship between hermetic storage at three different relative humidities, under different storage times (four months and seven months), temperature average and water activity, and the influence of hermetic storage on S. zeamais populations, and rice quality. The rice quality was evaluated based on the rheology behavior of rice aqueous pastes (Torres et al., 2013) from rice flour to detect structural changes at the macromolecule (mainly starch) level.

\section{Material and methods}

\subsection{Sample preparation}

Experiments were conducted in a warehouse, to store paddy, property of the rice farmers association of Sado Valley region, Portugal. Three trials were carried out from December to November: $\left[T_{1}\right]$ the first trial, four months, from December to April, corresponds to the mean storage time of paddy in this Association, before being delivered to the rice mills; $\left[\mathrm{T}_{2}\right]$ the second trial from December to July, seven months of storage; $\left[\mathrm{T}_{3}\right]$, the third trial, four months, from July to November, with higher average temperatures.

For all the experiments, GrainPro ${ }^{\circledR}$ SuperGrainbag ${ }^{\circledR}$ Farm ${ }^{\mathrm{TM}}$ bags were used to store two rice varieties: Ronaldo, Oryza sativa sbsp. japonica, (developed by Lugano Leonardo ${ }^{\circledR}$, Italy), and Sírio, Oryza sativa sbsp. indica (developed by SA.PI.SE., Italy). Both varieties are the most used by the farmers in 2015, 2016 and 2017, in Sado Valley. Same varieties were stored in jute bags, as the control. Both jute bags and SuperGrainbag ${ }^{\circledR}$ have a capacity of $50 \mathrm{~kg}$, and for each treatment and variety three replications were carried out. A total of 48 samples per trial were evaluated. The relative humidity and temperature were monitored by Hobo ${ }^{\circledR}$ Data loggers, with the probe placed inside the bags.

In all experiments, the two varieties were stored as paddy and submitted to three different relative humidities: $67 \%, 75 \%$ and $85 \%$ $\mathrm{RH}$, at three different average temperatures: $14^{\circ} \mathrm{C}, 17^{\circ} \mathrm{C}$ and $24^{\circ} \mathrm{C}$. The temperature recorded by the several data loggers are identical in all bags for the same trial, regardless of the humidity and type of rice. However the temperature varied during the storage period (Fig. 1). $\mathrm{T}_{1}$ had the temperature average of $14^{\circ} \mathrm{C}$ with no record above $20^{\circ} \mathrm{C}$; $\mathrm{T}_{2}$ had an average temperature of $17^{\circ} \mathrm{C}$ with 43 days above $20^{\circ} \mathrm{C}$ and 13 days above $25^{\circ} \mathrm{C} ; \mathrm{T}_{3}$ had the highest mean
Temperature $\left({ }^{\circ} \mathrm{C}\right)$

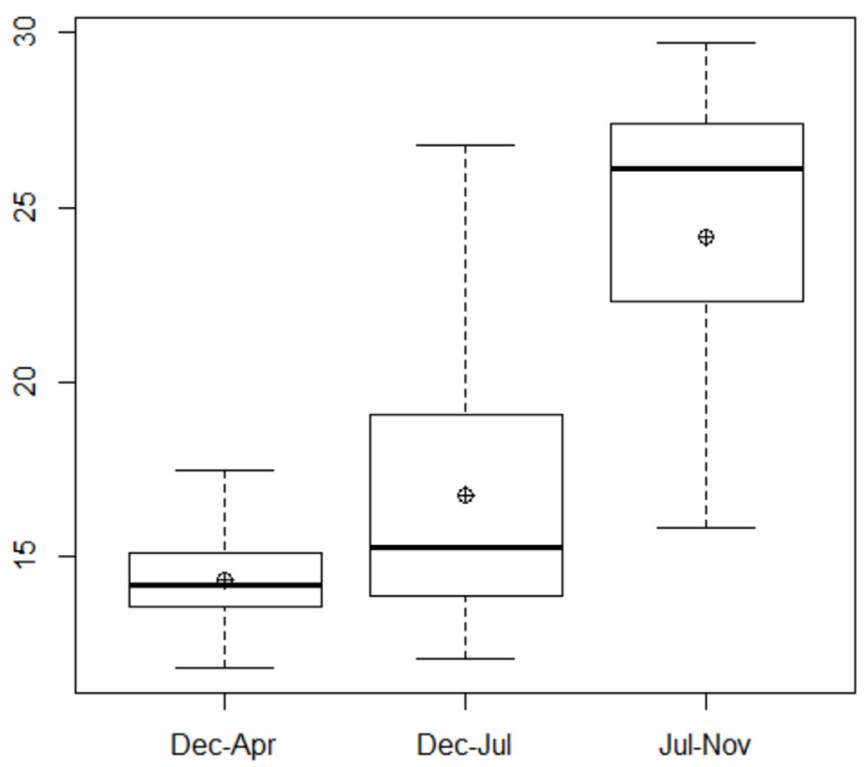

Fig. 1. Distribution of recorded temperature in each experiment. The thicker line represents the median (half of the records lies above the line) while the symbol represents the mean temperature across the entire experiment.

temperature, $24^{\circ} \mathrm{C}$, with 103 days above $20^{\circ} \mathrm{C}$, in which 60 days were over $25^{\circ} \mathrm{C}$ and 34 days above $27^{\circ} \mathrm{C}$ (Table 1 ). The December to July trial $\left[\mathrm{T}_{2}\right]$ was much longer than the other two experiments, while the highest temperatures occurred in the July to November trial (Fig. 1).

At the end of the four $\left(T_{1}\right.$ and $\left.T_{3}\right)$ and seven $\left(T_{2}\right)$ months of experiments, all bags were opened and paddy samples were collected. Before opening the bags, CheckpointII Portable $\mathrm{O}_{2}$ and $\mathrm{CO}_{2}$ Gas Analyzer was used to assess gas contents, at the bottom and top of each bag, making for a total of six measures per treatment, and the results registered. The gas content is expressed in terms of percentage by volume in air. Samples were taken to be dehusked and milled to analyse water activity $\left(\mathrm{a}_{\mathrm{w}}\right)$, with three replications per treatment. Rice pastes were prepared to perform the rheology tests.

HygroPalm HP23 Rotronic was used to estimate $\mathrm{a}_{\mathrm{w}}$, using three replications per treatment.

\subsection{Bioassays}

To evaluate the insects' response to each treatment, S. zeamais was chosen since it is the key pest of rice in Portugal (Carvalho et al., 2012a). S. zeamais was originally collected from Portuguese rice mills and reared in climatic chambers, at $25 \pm 2{ }^{\circ} \mathrm{C}$ and $70 \pm 2 \% \mathrm{RH}$, at our laboratory.

Table 1

Duration of each experiment in days, mean temperature and number of "hot days". 'number days' is the number of days with mean temperature greater then $20^{\circ} \mathrm{C}$, $25^{\circ} \mathrm{C}$ and $27^{\circ} \mathrm{C}$.

\begin{tabular}{llll}
\hline & {$\left[\mathrm{T}_{1}\right]$} & {$\left[\mathrm{T}_{2}\right]$} & {$\left[\mathrm{T}_{3}\right]$} \\
\hline Storage period (days) & 139 & 215 & 121 \\
Mean Temperature $\left({ }^{\circ} \mathrm{C}\right)$ & $14 \pm 1$ & $17 \pm 4$ & $24 \pm 3$ \\
number days with Temp $>20^{\circ} \mathrm{C}$ & 0 & 43 & 103 \\
number days with Temp $>25^{\circ} \mathrm{C}$ & 0 & 13 & 60 \\
number days with Temp $>27^{\circ} \mathrm{C}$ & 0 & 0 & 34 \\
\hline
\end{tabular}


For experiments, $20 \mathrm{~g}$ of brown rice were infested with oneweek-old of $\sim 20 \mathrm{~S}$. zeamais adults and placed inside paper bags. One paper bag was settled up inside of each paddy bag, totalizing three replications per treatment.

\subsection{Rheology measurements}

Rheology tests were carried out for $\mathrm{T}_{1}$ trial and performed on a MARS III controlled-stress rheometer (Haake) coupled with a temperature controlling Peltier unit, using a $35 \mathrm{~mm}$ diameter serrated parallel plates and $0.5 \mathrm{~mm}$ gap. Aqueous flour suspensions $(10 \% \mathrm{w} / \mathrm{w})$ were held $5 \mathrm{~min}$ at $20^{\circ} \mathrm{C}$, between the plates, before testing. Considering the following steps: (a) Heating curves from $20^{\circ} \mathrm{C}$ to $90^{\circ} \mathrm{C}\left(2^{\circ} \mathrm{C} / \mathrm{min}\right)$, oscillatory frequency of $0.1 \mathrm{~Hz}$; (b) Setting at $90^{\circ} \mathrm{C}$ during $1 \mathrm{~h}$; (c) Colling curves from $90^{\circ} \mathrm{C}$ to $5^{\circ} \mathrm{C}\left(-1^{\circ} \mathrm{C} / \mathrm{min}\right)$; (d) Maturation curve during $1 \mathrm{~h}$ at $5^{\circ} \mathrm{C}$; (e) Mechanical spectra with frequency range between 0.01 and $100 \mathrm{~Hz}$ at $20^{\circ} \mathrm{C}$. Then, the rheological study using SAOS (small amplitude oscillatory system) was performed according to previously optimized conditions (Torres et al., 2014).

\subsection{Data analysis}

All the computations and graphics were performed with the $\mathrm{R}$ software (R Core Team, 2017). Function $l m$ was used to fit and test for significance all the linear models. The simple linear regressions of $\mathrm{CO}_{2}$ vs $\mathrm{O}_{2}$ were fitted to 9 data points; for each experimental condition of temperature, relative humidity and storage time, the average of all gas measurements was used.

Linear models were also considered aiming at to relate the atmospheric composition at the end of each assay (oxygen content, carbon dioxide content and water activity) with the temperature, relative humidity and the trial duration. Each trial $\left(\mathrm{T} 1=14^{\circ} \mathrm{C}\right.$, 4months; $\mathrm{T} 2=17^{\circ} \mathrm{C}, 7$ months and $\mathrm{T} 3=12^{\circ} \mathrm{C}$, 4months) was carried out at three humidity conditions ( $\mathrm{RH}=67 \%, 75 \%$ and $85 \%)$. For each of these 9 experimental conditions all the individual measurements of $\mathrm{O}_{2}(6), \mathrm{CO}_{2}(6)$ and $\mathrm{a}_{\mathrm{w}}(3-10)$ were used to fit the linear models. These replications are based on independent samples.

Beside these linear models, a 2-way ANOVA with interaction model was fitted to the $\mathrm{O}_{2}$ and $\mathrm{a}_{\mathrm{w}}$ data using as factors: the combination temperature/time (Temp_time, with 3 levels: 14_4, 17_7 and 24_4) and the relative humidity (RH, with 3 levels: 67,75 and $85)$. The data collected for the two rice varieties were merged. For each of the 9 cells, two replications were used, each one corresponding to the average of the measurements for a rice variety. Thus, 18 observations were used to fit each 2-way ANOVA.

The same two-factor factorial design was used to analyse the relation between insect's growth and storage conditions. A 2-way ANOVA with interaction model was fitted to the progeny observed in each of the four to seven small bags containing rice initially contaminated with 20 insects. Globally 54 observations were used to fit the model.

The ANOVA models were fitted with the R function aov. The post hoc Tukey and Kruskal-Wallis with Fisher's least significant difference tests were performed with functions HSD.test and kruskal from package 'agricolae' (Mendiburu, 2017).

\section{Results}

\subsection{Gas content and water activity $\left(a_{w}\right)$}

The change in air composition was assessed by measuring the oxygen and carbon dioxide inside each bag at the end of each experiment. The carbon dioxide is linearly and negatively related to the oxygen content (Fig. 2). The straight lines are very precise (both $\mathrm{R}^{2}$ are close to 1 ) and similar for Indica and Japonica rice. In average, when the oxygen increases $1 \%$, the carbon dioxide decreases $1.16 \%$ for Indica and $1.29 \%$ for Japonica. When all the oxygen was consumed $\left(\mathrm{O}_{2} \approx 0 \%\right)$, the $\mathrm{CO}_{2}$ produced is slightly higher at Japonica rice than at Indica rice (Fig. 2).

After four months $\left(\mathrm{T}_{1}\right.$ and $\mathrm{T}_{3}$ ) and seven months $\left(\mathrm{T}_{2}\right)$ at different average temperatures, under $67 \% \mathrm{RH}$, there was no significant change in $\mathrm{O}_{2}$ and $\mathrm{CO}_{2}$ content. Therefore no respiration was detected, which is a sign of no biological activity. At higher relative humidity, there were changes on the gas content, indicating an increase on the respiration rate given by the significant decrease on $\mathrm{O}_{2}$ and increase on $\mathrm{CO}_{2}$ with the increase in $\mathrm{RH}$ (Fig. 3ab).

The change in air composition was complemented by evaluating water activity $\left(\mathrm{a}_{\mathrm{w}}\right)$ inside each bag at the end of experiment. The water activity $\left(\mathrm{a}_{\mathrm{w}}\right)$ at the end of the experiment, for each rice type (Indica and Japonica) showed a dependency on the environmental conditions and storage time (Fig. 4ab).

Linear models were considered aiming at to relate the atmospheric composition at the end of each assay (oxygen content, carbon dioxide content and water activity) with the temperature, relative humidity and the trial duration. For each parameter, two tested models were considered and compared through a partial $\mathrm{F}$ test: a complete model allowing a fit for each rice variety and a sub model that does not distinguish the rice varieties. According to the fitted linear models (all considered significant by the global $\mathrm{F}$ tests), the increase in temperature (keeping relative humidity and time unchanged) leads to a decrease in oxygen and an increase in carbon dioxide and water activity. Similarly, the increase in relative humidity (keeping the temperature and time constant) leads to a decrease in oxygen and an increase in carbon dioxide and water activity. The storage time (at constant temperature and humidity) has an effect of increasing the carbon dioxide and decreasing oxygen and water activity (Table 2).

The atmosphere composition $\left(\mathrm{O}_{2}\right.$ and $\left.\mathrm{CO}_{2}\right)$ depends in a similar way on the storage conditions (temperature, relative humidity and time) for both rice varieties, since the p-values of the partial $F$ tests

\section{Indica and Japonica}

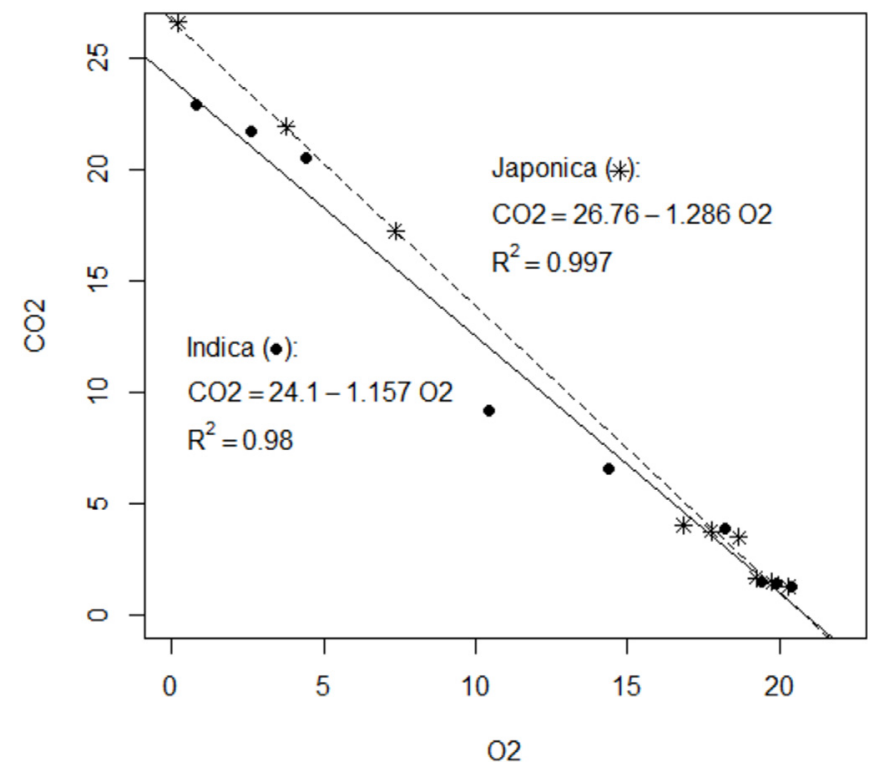

Fig. 2. Relation between the average values of carbon dioxide $\left(\mathrm{CO}_{2} \%\right)$ and oxygen $\left(\mathrm{O}_{2} \%\right)$, measured at the end of each experiment 

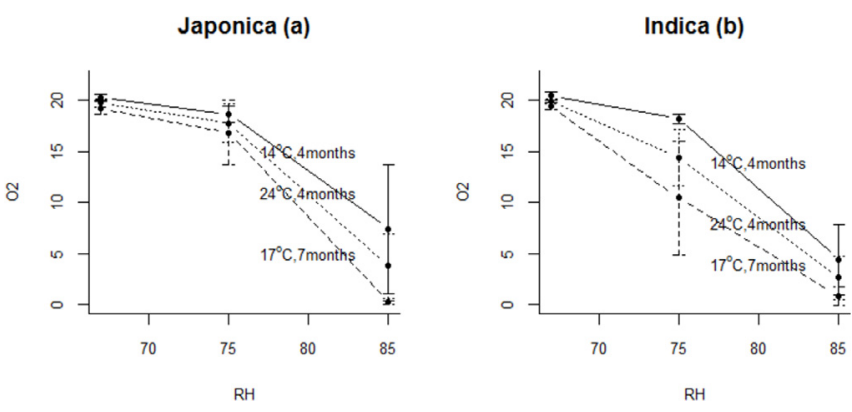

Fig. 3. (a) - Amount of $\mathrm{O}_{2}(\%)$ at the end of the experiment, for Japonica rice and each environmental storage condition (Temperature in ${ }^{\circ} \mathrm{C}$, time in months and $\mathrm{RH}$ in \%). The vertical bars indicate the standard deviation of the replications. (b)- Amount of $\mathrm{O}_{2}(\%)$ at the end of the experiment, for Indica rice and each environmental storage condition (Temperature in ${ }^{\circ} \mathrm{C}$, time in months and $\mathrm{RH}$ in \%). The vertical bars indicate the standard deviation of the replications.
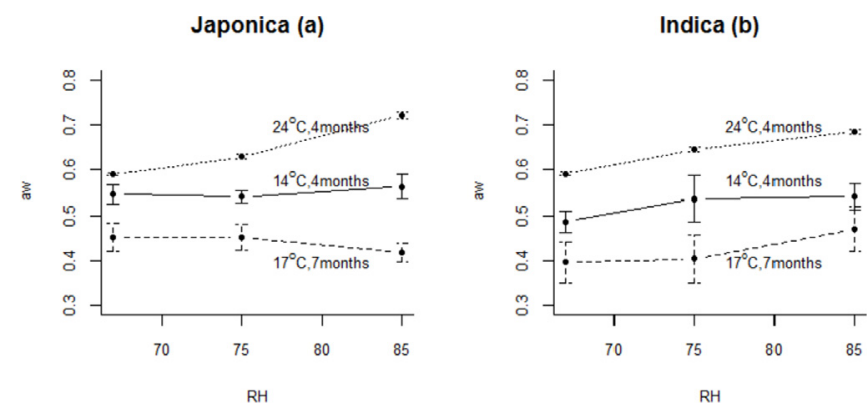

Fig. 4. (a) - Water activity $\left(a_{w}\right)$ at the end of the experiment, for Japonica rice and each environmental storage condition (Temperature in ${ }^{\circ} \mathrm{C}$, time in months and $\mathrm{RH}$ in \%). The vertical bars indicate the standard deviation of the replications. (b) - Water activity $\left(a_{w}\right)$ at the end of the experiment, for Indica rice and each environmental storage condition (Temperature in ${ }^{\circ} \mathrm{C}$, time in months and $\mathrm{RH}$ in \%). The vertical bars indicate the standard deviation of the replications.

comparing the unique model for both rice varieties with a model for each rice variety are greater than 0.05 (Table 2).

The fitted 2-way ANOVA model shows that the factors Temp_time and $\mathrm{RH}$ affect significantly ( $\mathrm{p}$-values $<0.05$ ) the oxygen content and water activity in the hermetic bag's atmosphere, while the interaction effect was not significant.

The results obtained by a post-hoc Tukey HSD test show no significant differences in mean $\mathrm{O}_{2}$ content for all the trials under $67 \%$ and $75 \% \mathrm{RH}$. However, a significant decrease on $\mathrm{O}_{2}$ content occurs during experiments under $85 \% \mathrm{RH}$. Although not significant, at same $\mathrm{RH}$, a decrease on $\mathrm{O}_{2}$ is observed with the increase of storage time and of average temperature, for the 4 months trials (Table 3).

Regarding $\mathrm{a}_{\mathrm{w}}$, the water activity increases with the increase of temperature and $\mathrm{RH}$, for the same storage time, and decreases with the increase of storage time, although the differences are not always significant (Table 3 ).

\subsection{Sitophilus zeamais survival at different environmental conditions and atmospheres}

Even if the population growth of $S$. zeamais versus storage environmental conditions did not fit any linear model tested, there are patterns of note in the obtained data (Tables 4 and 5). When the total of insects were considered, the first 20 weevils adults used per replication were subtracted from the sum of alive and dead insects, to better understand if there was progeny during the trials.

Some differences on insects' growth were observed when comparing the obtained results for the two rice varieties: experiments with Indica rice showed that, at oxygen content below 4.4\% there was almost no progeny, whatever the average temperature of the trials (Table 4). Experiments with Japonica rice no progeny was achieved under $3.8 \%$ of $\mathrm{O}_{2}$ content. Contradictory results were obtained, where a progeny of 5.3 adults was recorded at oxygen content of $0.2 \%$ (Table 5 ).

Since the MA at Indica and Japonica rice seems similar (Table 2), the results were merged in order to globally appreciate the relation between progeny and the storage conditions (Fig. 5). We applied a 2-way ANOVA for progeny using the factors Temp_time (3 levels: 14_4, 17_7 and 24_4) and RH (3 levels: 67, 75 and 85). The data for all the paper bags were used. The principal effects of both factors and the interaction effect were significant ( $p$-values $<0.001$ ). In order to analyse which storage conditions produce significant differences in progeny, the means and the ranks of the number of adults per vial were compared through a post-hoc Tukey HSD test and a Kruskal-Wallis test with the Fisher's least significant difference method (Table 6).

The highest population growth occurs under $24{ }^{\circ} \mathrm{C}$ and $67 \% \mathrm{RH}$ (Table 6, Fig. 5), storage conditions where atmosphere content remained almost unchanged (Table 3 ). On the other hand, the highest mortality occurs under $85 \%$ RH (Table 6, Fig. 5), where the oxygen content in the storage atmosphere has a significant decrease (Table 3).

\subsection{Rheological measurements}

Rheological tests were carried out for $T_{1}$ experiments, from December to April, to evaluate the impact of relative humidity even

Table 2

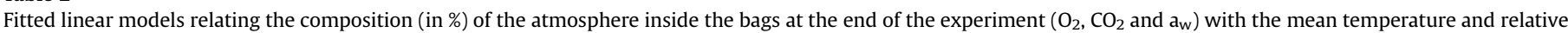

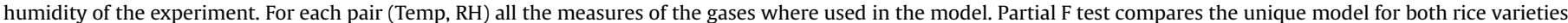
with the complete model that distinguishes the rice varieties.

\begin{tabular}{|c|c|c|c|}
\hline Fitted Models & $\mathrm{R}^{2}$ & p-value (global F test) & p-value (partial F test) \\
\hline \multicolumn{4}{|l|}{ Indica } \\
\hline $\mathrm{O}_{2}=95.62-0.209 \mathrm{Temp}-0.971 \mathrm{RH}-1.200$ time & 0.878 & $<0.01$ & \\
\hline $\mathrm{CO}_{2}=-83.35+0.134 \mathrm{Temp}+1.149 \mathrm{RH}+0.766$ time & 0.872 & $<0.01$ & \\
\hline $\begin{array}{l}\mathrm{a}_{\mathrm{w}}=0.193+0.0120 \mathrm{Temp}+0.00437 \mathrm{RH}-0.0433 \text { time } \\
\text { Japonica }\end{array}$ & 0.817 & $<0.01$ & \\
\hline $\mathrm{O}_{2}=90.59-0.170 \mathrm{Temp}-0.909 \mathrm{RH}-0.972$ time & 0.782 & $<0.01$ & \\
\hline $\mathrm{CO}_{2}=-87.50+0.175 \mathrm{Temp}+1.167 \mathrm{RH}+1.00$ time & 0.785 & $<0.01$ & \\
\hline $\begin{array}{l}\mathrm{a}_{\mathrm{w}}=0.520+0.00993 \mathrm{Temp}+0.000849 \mathrm{RH}-0.0442 \text { time } \\
\text { Indica }+ \text { Japonica }\end{array}$ & 0.852 & $<0.01$ & \\
\hline $\mathrm{O}_{2}=93.10-0.190 \mathrm{Temp}-0.940 \mathrm{RH}-1.086$ time & 0.822 & $<0.01$ & 0.858 \\
\hline $\mathrm{CO}_{2}=-85.42+0.155 \mathrm{Temp}+1.158 \mathrm{RH}+0.883$ time & 0.824 & $<0.01$ & 0.199 \\
\hline $\mathrm{a}_{\mathrm{w}}=0.350+0.0111$ Temp $+0.00263 \mathrm{RH}-0.0431$ time & 0.808 & $<0.01$ & 0.017 \\
\hline
\end{tabular}


Table 3

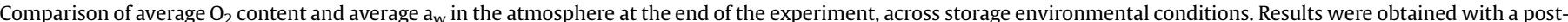

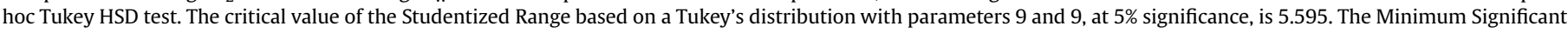
Difference is 7.420 for $\mathrm{O}_{2}$ and 0.111 for $\mathrm{a}_{\mathrm{w}}$. Treatments with the same letter are not significantly different at a $5 \%$ significance.

\begin{tabular}{|c|c|c|c|c|c|}
\hline \multicolumn{3}{|l|}{$\mathrm{O}_{2}$} & \multicolumn{3}{|l|}{$\mathrm{a}_{\mathrm{w}}$} \\
\hline Temp $\left({ }^{\circ} \mathrm{C}\right)_{-}$time (months) & RH (\%) & $\mathrm{O}_{2}(\%)$ & Temp $\left({ }^{\circ} \mathrm{C}\right)_{-}$time (months) & $\mathrm{RH}(\%)$ & $a_{w}$ \\
\hline 14_4 & 67 & $20.37^{a}$ & $24 \_4$ & 85 & $0.703^{a}$ \\
\hline $24 \_4$ & 67 & $19.85^{\mathrm{a}}$ & $24 \_4$ & 75 & $0.638^{\mathrm{ab}}$ \\
\hline 17_7 & 67 & $19.33^{\mathrm{a}}$ & $24 \_4$ & 67 & $0.591^{\mathrm{bc}}$ \\
\hline 14_4 & 75 & $18.43^{\mathrm{a}}$ & $14 \_4$ & 85 & $0.552^{\text {bcd }}$ \\
\hline $24 \_4$ & 75 & $16.06^{\mathrm{a}}$ & $14 \_4$ & 75 & $0.538^{\mathrm{bcd}}$ \\
\hline 17_7 & 75 & $13.65^{\mathrm{a}}$ & $14 \_4$ & 67 & $0.516^{\text {cde }}$ \\
\hline 14_4 & 85 & $5.88^{\mathrm{b}}$ & 17_7 & 85 & $0.444^{\text {de }}$ \\
\hline $24 \_4$ & 85 & $3.19^{\mathrm{b}}$ & 17_7 & 75 & $0.427^{\mathrm{e}}$ \\
\hline 17_7 & 85 & $0.50^{\mathrm{b}}$ & 17_7 & 67 & $0.424^{\mathrm{e}}$ \\
\hline
\end{tabular}

Table 4

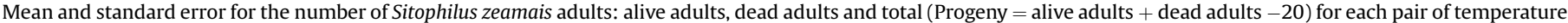

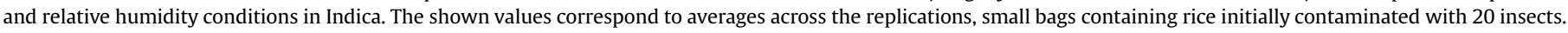
The amounts of oxygen $\left(\mathrm{O}_{2}\right.$, \%), carbon dioxide $\left(\mathrm{CO}_{2}, \%\right)$ and water activity $\left(\mathrm{a}_{\mathrm{w}}\right)$ at the end of each experiment are also shown.

\begin{tabular}{|c|c|c|c|c|c|c|c|c|}
\hline \multicolumn{2}{|c|}{$\begin{array}{l}\text { Temp }\left({ }^{\circ} \mathrm{C}\right) \text { _time } \\
\text { (months) }\end{array}$} & \multirow{2}{*}{$\begin{array}{l}\mathrm{RH}(\%) \\
85\end{array}$} & \multirow{2}{*}{$\begin{array}{l}\mathrm{CO}_{2}(\%) \\
20.6\end{array}$} & \multirow{2}{*}{$\begin{array}{l}\mathrm{O}_{2}(\%) \\
4.4\end{array}$} & \multirow{2}{*}{$\begin{array}{l}\mathrm{a}_{\mathrm{w}} \\
0.541\end{array}$} & \multirow{2}{*}{$\begin{array}{l}\text { Alive adults mean } \pm \text { SE } \\
10.3 \pm 5.4\end{array}$} & \multirow{2}{*}{$\begin{array}{l}\text { Dead adults mean } \pm \text { SE } \\
7.7 \pm 5.4\end{array}$} & \multirow{2}{*}{$\begin{array}{l}\text { Progeny mean } \pm S E \\
0^{\mathrm{a}}\end{array}$} \\
\hline $\mathrm{T}_{1}$ & 14_4 & & & & & & & \\
\hline & 14_4 & 75 & 3.9 & 18.3 & 0.536 & $13.7 \pm 1.5$ & $37.3 \pm 6.9$ & $31 \pm 8.4$ \\
\hline & 14_4 & 67 & 1.2 & 20.4 & 0.486 & $4.3 \pm 1.5$ & $44.5 \pm 8.1$ & $28.8 \pm 8.4$ \\
\hline \multirow[t]{3}{*}{$\mathrm{T}_{2}$} & $24 \_4$ & 85 & 21.8 & 2.6 & 0.685 & $0.0 \pm 0.0$ & $20.0 \pm 0.0$ & $0.0 \pm 0.0$ \\
\hline & 24_4 & 75 & 6.5 & 14.4 & 0.646 & $86.3 \pm 29.6$ & $64.0 \pm 16.6$ & $130.3 \pm 45.9$ \\
\hline & 24_4 & 67 & 1.4 & 19.9 & 0.591 & $84.0 \pm 14.7$ & $93.3 \pm 26.7$ & $157.3 \pm 40.9$ \\
\hline \multirow[t]{3}{*}{$\mathrm{T}_{3}$} & 17_7 & 85 & 23 & 0.8 & 0.470 & $0.7 \pm 0.7$ & $20.3 \pm 0.9$ & $1.0 \pm 1.5$ \\
\hline & 17_7 & 75 & 9.2 & 10.5 & 0.403 & $24.5 \pm 16.5$ & $46.0 \pm 6.0$ & $50.5 \pm 22.5$ \\
\hline & 17_7 & 67 & 1.5 & 19.4 & 0.396 & $8.5 \pm 4.9$ & $33.8 \pm 9.6$ & $22.3 \pm 13.9$ \\
\hline
\end{tabular}

${ }^{a}$ At the end less than 20 insects were found.

Table 5

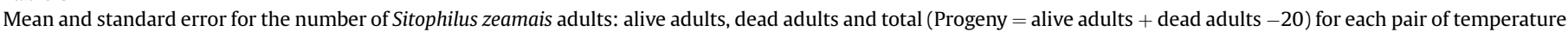

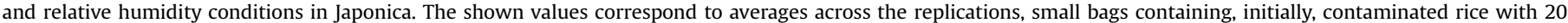
insects. The amounts of oxygen $\left(\mathrm{O}_{2}\right.$, \%), carbon dioxide $\left(\mathrm{CO}_{2}, \%\right)$ and water activity content $\left(\mathrm{a}_{\mathrm{w}}\right)$ at the end of each experiment are also shown.

\begin{tabular}{|c|c|c|c|c|c|c|c|c|}
\hline \multicolumn{2}{|c|}{$\begin{array}{l}\text { Temp }\left({ }^{\circ} \mathrm{C}\right) \text { time } \\
\text { (months) }\end{array}$} & \multirow{2}{*}{$\begin{array}{l}\mathrm{RH}(\%) \\
85\end{array}$} & \multirow{2}{*}{$\begin{array}{l}\mathrm{CO}_{2}(\%) \\
17.3\end{array}$} & \multirow{2}{*}{$\begin{array}{l}\mathrm{O}_{2}(\%) \\
7.4\end{array}$} & \multirow{2}{*}{$\begin{array}{l}\mathrm{a}_{\mathrm{w}} \\
0.563\end{array}$} & \multirow{2}{*}{$\begin{array}{l}\text { Alive adults mean } \pm S E \\
27.7 \pm 6.9\end{array}$} & \multirow{2}{*}{$\begin{array}{l}\text { Dead adults mean } \pm S E \\
9.3 \pm 1.3\end{array}$} & \multirow{2}{*}{$\begin{array}{l}\text { Progeny mean } \pm S E \\
17.0 \pm 6.0\end{array}$} \\
\hline $\mathrm{T}_{1}$ & $14-4$ & & & & & & & \\
\hline & $14-4$ & 75 & 3.5 & 18.7 & 0.540 & $12.5 \pm 5.3$ & $41.0 \pm 7.2$ & $33.5 \pm 6.0$ \\
\hline & $14-4$ & 67 & 1.3 & 20.3 & 0.545 & $1.3 \pm 0.9$ & $69.7 \pm 37.8$ & $51 \pm 37.7$ \\
\hline \multirow[t]{3}{*}{$\mathrm{T}_{2}$} & $24-4$ & 85 & 26.7 & 0.2 & 0.721 & $0.0 \pm 0.0$ & $20.0 \pm 0.0$ & $0.0 \pm 0.0$ \\
\hline & $24-4$ & 75 & 4.0 & 16.9 & 0.629 & $16.0 \pm 6.8$ & $43.0 \pm 23.1$ & $39.0 \pm 28.7$ \\
\hline & $24-4$ & 67 & 1.6 & 19.3 & 0.590 & $108.0 \pm 4.0$ & $71.0 \pm 16.0$ & $159.0 \pm 20.0$ \\
\hline \multirow[t]{3}{*}{$\mathrm{T}_{3}$} & $17-7$ & 85 & 22.0 & 3.8 & 0.417 & $0.0 \pm 0.0$ & $25.3 \pm 3.4$ & $5.3 \pm 3.4$ \\
\hline & $17-7$ & 75 & 3.8 & 17.8 & 0.451 & $36.5 \pm 16.5$ & $20.0 \pm 17.0$ & $36.5 \pm 0.5$ \\
\hline & $17-7$ & 67 & 1.4 & 19.8 & 0.452 & $3.3 \pm 1.3$ & $32.3 \pm 4.5$ & $15.7 \pm 3.7$ \\
\hline
\end{tabular}

Number of Sitophilus (alive|dead) (a)

Number of Sitophilus (b)

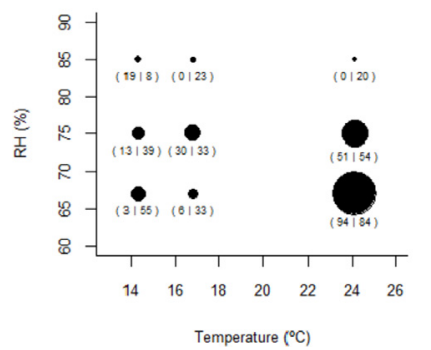

Fig. 5. (a) - Population growth of Sitophilus zeamais, for each pair of temperature $\left({ }^{\circ} \mathrm{C}\right)$ and relative humidity $(\mathrm{RH}, \%)$ conditions. The area of each circle is proportional to the sum $S$. alive $+S$. dead, while the values below each circle correspond to alive adults (left) and dead adults (right). (b) - Population growth of Sitophilus zeamais for each pair of temperature $\left({ }^{\circ} \mathrm{C}\right)$ and oxygen content $(\%)$. The area of each circle is proportional to the sum alive adults + dead adults. under hermetic conditions, corresponding to the storage time at on-farm facilities. The flours were obtained by milling the rice subjected to storage. In these tests, the viscoelastic parameters G' (storage or elastic modulus) and G" (loss or viscous modulus) of the rice pastes, are measured. The viscoelastic behaviour of the gel pasts was considered as an indicator for the technological aptitude of each rice.

Fig. 6 ab shows the gelling point (when $\mathrm{G}^{\prime}$ crosses over $\mathrm{G}^{\prime \prime}$ ) of $10 \%$ $(\mathrm{w} / \mathrm{w})$ pastes of Japonica and Indica rice flour heated from $20^{\circ} \mathrm{C}$ to $90^{\circ} \mathrm{C}$, at the inflexion point of the graph (around $85^{\circ} \mathrm{C}$ ) under the three different RHs. At the Japonica rice paste, there is a slight decrease in the gelling point temperature with the increase of $\mathrm{RH}$ : hermetic storage at $67 \% \mathrm{RH}$ and control started gelling at about $87^{\circ} \mathrm{C}$; hermetic storage under $75 \%$ and $85 \% \mathrm{RH}$, started gelling at $85^{\circ}$ and $82^{\circ} \mathrm{C}$, respectively. For the Indica rice pastes, the results were reversed: the control and hermetic storage at $85 \% \mathrm{RH}$ started gelling at $85^{\circ} \mathrm{C}$ and both hermetic conditions of $67 \%$ and $75 \% \mathrm{RH}$, 
Table 6

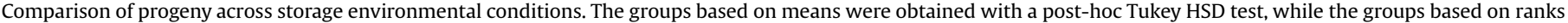

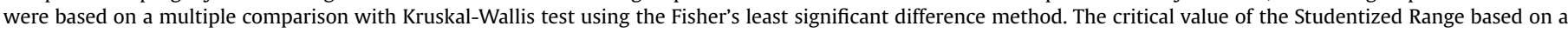

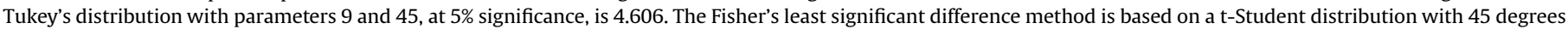
of freedom. Treatments with the same letter are not significantly different at a $5 \%$ significance.

\begin{tabular}{|c|c|c|c|}
\hline \multicolumn{2}{|l|}{ Treatment } & \multicolumn{2}{|l|}{ Progeny } \\
\hline Temp $\left({ }^{\circ} \mathrm{C}\right)_{-}$time (months) & $\mathrm{RH}(\%)$ & mean $\pm S E$ (adults per vial) & rank of adults per vial \\
\hline 24_4 & 67 & $158.0 \pm 23.3^{\mathrm{a}}$ & $50.4^{\mathrm{a}}$ \\
\hline $24 \_4$ & 75 & $84.7 \pm 31.7^{b}$ & $37.5^{\mathrm{b}}$ \\
\hline $17 \_7$ & 75 & $43.5 \pm 10.0^{\mathrm{bc}}$ & $37.8^{\mathrm{ab}}$ \\
\hline $14 \_4$ & 67 & $38.3 \pm 15.6^{\mathrm{bc}}$ & $31.7^{\mathrm{bc}}$ \\
\hline $14 \_4$ & 75 & $32.4 \pm 4.6^{\mathrm{bc}}$ & $34.1^{\mathrm{bc}}$ \\
\hline 17_7 & 67 & $19.7 \pm 7.5^{c}$ & $24.9^{\mathrm{cd}}$ \\
\hline $14 \_4$ & 85 & $8.5 \pm 4.7^{c}$ & $15.9^{\mathrm{de}}$ \\
\hline $17 \_7$ & 85 & $3.3 \pm 1.9^{c}$ & $14.0^{\mathrm{de}}$ \\
\hline $24 \_4$ & 85 & $0.0 \pm 0.0^{c}$ & $7.0^{\mathrm{e}}$ \\
\hline
\end{tabular}

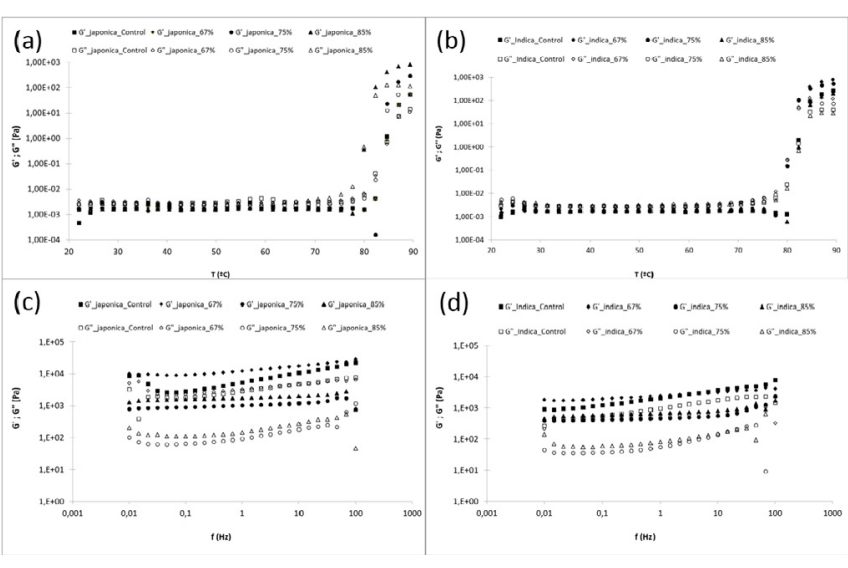

Fig. 6. (a)-(b) - Starch gelatinization of the rice paste. Heating from $20^{\circ} \mathrm{C}$ to $90{ }^{\circ} \mathrm{C}$ at $2{ }^{\circ} \mathrm{C} / \mathrm{min}$ ( $\mathrm{G}^{\prime}$ elastic modulus; $\mathrm{G}^{\prime \prime}$ viscous modulus). (a) - Japonica Rice; (b) - Indica Rice. (c)-(d) - Mechanical spectra at $20^{\circ} \mathrm{C}\left(\mathrm{G}^{\prime}\right.$ - elastic modulus; $\mathrm{G}^{\prime \prime}$ - viscous modulus). (c) Japonica Rice; (d) - Indica Rice.

started gelling at $82^{\circ} \mathrm{C}$.

Fig. 6cd shows the mechanical spectra of the rice pastes by variety and relative humidity conditions. The paste obtained from rice stored at lower $\mathrm{RH}$ values, i.e., $67 \%$, is slightly more structured than rice stored at higher humidity and control, i.e. the values of the viscoelastic parameters $G^{\prime}$ and $G^{\prime \prime}$ are slightly higher for the pastes from rice stored under lower RH conditions, showing a better structured paste (Nunes et al., 2006).

\section{Discussion}

During the present study, S. zeamais showed distinct behaviour under low oxygen contents: no progeny was found under $3.8 \% \mathrm{O}_{2}$ content, but under $0.2 \%$ of $\mathrm{O}_{2}$ the progeny registered an average of 5.3 adults. The response of stored-products insects to changes in $\mathrm{O}_{2}$ and $\mathrm{CO}_{2}$ contents differs within different species. For the majority of stored-product insects, the lower the oxygen concentration, the shorter the exposure time necessary to produce the complete kill. Navarro (1978) considered that this rule, on the oxygen deficit theory, has a classical exception with the Sitophilus spp. This species has been identified as amongst the most tolerant stored product insects to $\mathrm{CO}_{2}$ rich atmospheres (Annis, 1987). Fleurat-Lessard and Le Torc'h (1986) observed that few immature stages of $S$. granarius were susceptible the treatment of $1 \% \mathrm{O}_{2}$ under $10^{\circ}$ to $12^{\circ} \mathrm{C}$ and the exposure periods of 3 weeks were necessary to kill adults. Other authors reported that the development of insects can be prevented when $\mathrm{O}_{2}$ is blow $3 \%$ in the hermetic storage container within 30 days (Moreno-Martinez et al., 2000; Adhikarinayake et al., 2006). In Portugal, a 40t silo with polished rice under controlled atmospheres of $87.5 \% \mathrm{CO}_{2}$ and $2.6 \% \mathrm{O}_{2}$, during 10 days, two S. zeamais adults were alive, one in the sample nearest $\mathrm{CO}_{2}$ entrance (Carvalho et al., 2012a). Njoroge et al. (2017) registered that acoustic activity rates dropped down of adult Sitophilus oryzae as oxygen fell below $5 \%$ and mortality was observed at $2 \%$ levels. Donahaye et al. (2001) demonstrated that exposure to $\mathrm{O}_{2}$ levels of $3 \%$ and $5 \%$, imparted a metabolic stress on adults and hypoxia at $2-5 \% \mathrm{O}_{2}$. Other authors reported controversial results. For instance Conyers and Bell (2007) mentioned that an increase of $\mathrm{CO}_{2}$ to 10 or $20 \%$, reducing $\mathrm{O}_{2}$ to $5 \%$, was sufficient to eliminate the emergence of $\mathrm{S}$. granarius at $20^{\circ} \mathrm{C}$, but a few individuals emerged at $25^{\circ} \mathrm{C}$.

Modified atmosphere was naturally produced inside the hermetic bag under $85 \% \mathrm{RH}$, despite average temperature. Our results showed the importance of the relative humidity, average temperature and time as factors for the modification of the atmosphere content of paddy rice, hermetically stored. The modification of the air composition changes with the increase of the relative humidity, temperature, and storage time. Water activity decreases with storage time. Calderon and Navarro (1980) considered that when $\mathrm{CO}_{2}$ is added to low $\mathrm{O}_{2}$ atmospheres, there is a synergistic effect, from the significant interaction between the concentrations of these two gases. Carbon dioxide contents above 35\% by volume of air were reported, by several authors, to be lethal to insects (Banks, 1983ab; Annis and van Graver, 1986; Fleurat-Lessard, 1990; FleuratLessard and Le Torc'h, 1991), which was not attained in our experiments. Similar experiments using superbags, GrainPro ${ }^{\circledR}$ SuperGrainbag ${ }^{\mathbb{B}}$ Farm $^{\mathrm{TM}}$, to store paddy rice during six months, were made in Mozambique, a tropical country (Guenha et al., 2014). The average temperature was $24^{\circ} \mathrm{C}$ and moisture content $12 \%$. At end of the trials, comparing traditional storage (jute bags) with hermetic storage results, there was a decrease of $96 \%$ of insect population on paddy stored hermetically. The gas content was not measured. Donahaye et al. (2001) considered that the influence of temperature on insect respiration, in tropical countries, showed that the $\mathrm{O}_{2}$ intake by insects is very intensive and $\mathrm{O}_{2}$ reduction may be rapid. Conversely in temperate regions, insects' metabolism is slower and insect control may not be achieved. In our experiments it was the influence of relative humidity, together with temperature and time of storage that influenced the $\mathrm{O}_{2}$ and $\mathrm{CO}_{2}$ content.

The modification of gas content had impact on the rheology of the rice pastes. The increase on respiration rate reduced the viscoelastic functions and changed the starch gelatinization point of Indica and Japonica rice, showing an impact on rice quality affecting the starch molecules. The increase on respiration rate, as an indirect measure of insects or grain physiological activity, registered for higher values of $\mathrm{RH}$, reduced the viscoelastic functions and changed 
the starch gelatinization point of Indica and Japonica rice. Both insects and grain respiration affect starch, reducing the length of the starch macromolecule by hydrolysis, accessed through a glucose monomer, having a negative impact on the quality of the rice (Lagarrigue and Alvarez, 2001). Storing paddy hermetically at low relative humidity, did not change atmospheric content and maintained the viscoelastic functions of the rice pastes. Indica variety started gelling between $82^{\circ} \mathrm{C}$ and $84^{\circ} \mathrm{C}$ whatever the RH at storage. Japonica variety showed different behaviour: with the increase of the relative humidity the temperature of the gelling decreased.

At Portuguese conditions, using hermetic storage to store paddy rice at $67 \% \mathrm{RH}$, might not change the air composition, but avoid grain activity and maintain rice quality.

\section{Acknowledgement}

This study was supported by national funds from Portuguese Foundation for Science and Technology (FCT), through the research units UID/AGR/04129/2013-LEAF and UID/AGR/00239/2013-CEF and by the project RECI/AGR-TEC/0285/2012, BEST-RICE-4-LIFE "Development of a comprehensive system of quality of the rice, using image analysis, physical-chemical, sensory and chemometric tools to improve the quality of culture and the value of use". This study aims the objective of the FoodMC - COST Action CA15118, "Mathematical and Computer Science Methods for Food Science and Industry".

The authors want to give a special thanks to the AparrozAgrupamento de Produtores de Arroz do Vale do Sado Lda, particularly to the leader João Reis Mendes and the technician Nuno Nascimento who contributed to the success of the trials.

\section{References}

Adhikarinayake, T.B., Palipane, K.B., Müller, J., 2006. Quality changes and mass loss of paddy during airtight storage in a ferro-cement bin in Sri Lanka. J. Stored Prod. Res. 42, 377-390.

Adler, C., Corinth, H.G., Reichmuth, C., 2000. Chapter 5. Modified atmospheres. In: Subramanyam, B., Hagstrum, D.W. (Eds.), Alternatives to Pesticides in Storedproduct IPM. Springer US, pp. 105-146, 978-1-4613-6956-1 (Print) 978-14615-4353-4 (Online).

Annis, P.C., 1987. Towards rational controlled atmosphere dosage schedules: a review of current knowledge. In: Donahaye, E., Navarro, S. (Eds.), Proceedings of the 4th International Working Conference on Stored-products Protection. Tel Aviv, Israel, pp. 128-148.

Annis, P.S., Graver, J., Van, S., 1986. Use of carbon dioxide and sealed storage to control insects in bagged grain and similar commodities. In: Champ, B.R. Highley, E. (Eds.), Proc. Pesticides and Humid Tropical Grain Storage Systems. ACIAR Proceedings, vol. 14. ACIAR, Canberra, Australia, p. 364, 313-321.

Banks, H.J., 1983a. Modified atmosphere and hermetic storage-effects on insect pests and the commodity. In: Champ, B.R., Highley, E. (Eds.), Proc. Aust. Dev. Course on Preservation of Stored Cereals, pp. 521-532.

Banks, H.J., 1983b. Modified atmospheres-hermetic storage. In: Champ, B.R. Highley, E. (Eds.), Proc. Aust. Dev. Asst. Course on Preservation of Stored Cereals, pp. 558-573.

Calderon, M., Navarro, S., 1980. Synergistic effect of $\mathrm{CO}_{2}$ and $\mathrm{O}_{2}$ mixtures on two stored grain insect pests. Develop. Agric. Eng. 1, 79-84.

Carvalho, M.O., Pires, I., Barbosa, A., Barros, G., Riudavets, J., Garcia, A.C., Brites, C., Navarro, S., 2012a. The use of modified atmospheres to control Sitophilus zeamais and Sitophilus oryzae on stored rice in Portugal. J. Stored Prod. Res. 50, 49-56.

Carvalho, M.O., Barbosa, B., Barros, G., Magro, A., Adler, C., Navarro, S., Riudavets, J., Timlick, B., 2012b. Quality preservation of stored rice using modified atmospheres in Portugal. In: Navarro, S., Banks, J.H., Jayas, D., Bell, C.H., Noyes, R.T., Feizli, A.G., Emekci, M., Isikber, A.A., Alagusundaram, K. (Eds.), Proc. 9th Int. Conf. Controlled Atmospheres and Fumigation in Stored Products, 15-19 Out 2012. CAF, Antalya, Turkey, pp. 156-165.

Conyers, S.T., Bell, C.H., 2007. A novel use of modified atmospheres: storage insect population control. J. Stored Prod. Res. 43, 367-374.

Donahaye, E.J., Navarro, S., Leesch, J.G., 2001. In: Proc. Int. Conf. Controlled Atmosphere and Fumigation in Stored Products, Fresno, CA. Oct. 2000. Executive Printing Services, Clovis, CA, U.S.A., pp. 26-34

Fleurat-Lessard, F., 1990. Chapter 3. The effect of modified atmospheres on insects and mites infesting stored products. In: Calderon, M., Barkai-Golan, R. (Eds.), Food Preservation by Modified Atmospheres. CRC Press, pp. 21-38.

Fleurat-Lessard, F., Le Torc'h, J.M., 1986. Practical approach to purging grain with low oxygen atmosphere for disinfestation of large wheat bins against the granary weevil, Sitophilus granary. In: Donahaye, E., Navarro, S. (Eds.), Proc. 4th Int. Working Conf. on Stored-product Protection, Tel-Aviv, pp. 208-217.

Fleurat-Lessard, F., Le Torc'h, J.M., 1991. Influence de la teneur en oxygène sur la sensibilité de certains stades juveniles de Sitophilus oryzae et Sitophilus granarius au dioxide de carbone. Entomol. Exp. Appl. 58, 37-47.

Guenha, R., Salvador, B., das, V., Rickman, J., Goulao, L.F., Muocha, I.M., Carvalho, M.O., 2014. Hermetic storage with plastic sealing to reduce insect infestation and secure paddy seed quality: a powerful strategy for rice farmers in Mozambique. J. Stored Prod. Res. 59, 275-281.

Jayas, D.S., Jeyamkondan, S., 2002. Modified atmosphere storage of grains meats fruits and vegetables. Biosyst. Eng. 82 (3), 235-251.

Lagarrigue, S., Alvarez, G., 2001. The rheology of starch dispersions at high temperatures and high shear rates: a review. J. Food Eng. 50 (4), 189-202.

Mendiburu, F., 2017. 'agricolae': Statistical Procedures for Agricultural Research. R package version 1.2-8. https://CRAN.R-project.org/package $=$ agricolae.

Moreno-Martinez, E., Jiménez, S., Vázquez, M.E., 2000. Effect of Sitophilus zeamais and Aspergillus chevalieri on the oxygen level in maize stored hermetically. J. Stored Prod. Res. 36, 25-36.

Navarro, S., 1978. The effects of low oxygen tensions on three stored-product insect pests. Phytoparasitica 6, 51-58.

Navarro, S., 2006. Chapter 11. Modified atmospheres for the control of storedproduct insects and mites. In: Heaps, J.W. (Ed.), Insect Management for Food Storage and Processing, second ed. AACC International, pp. 105-146.

Njoroge, A.W., Mankin, R.W., Smith, B.W., Baributsa, D., 2017. Effects of hermetic storage on adult Sitophilus oryzae L. (Coleoptera: Curculionidae) acoustic activity patterns and mortality. J. Econ. Entomol. 110 (6), 2707-2715.

Nunes, M.C., Raymundo, A., Sousa, I., 2006. Rheological behaviour and microstructure of pea protein/kappa-carrageenan/starch gels with different setting conditions. Food Hydrocolloids 20, 106-113.

R Core Team, 2017. R: a Language and Environment for Statistical Computing. R Foundation for Statistical Computing, Vienna, Austria. http://www.R-project. org/.

Sinha, J.P., Jha, S., Atwal, S.S., Sinha, S.N., 2010. Post Harvest Management of Paddy Seed. Indian Agricultural Research Institute. Regional Station, Karnal - 132 001, TB-ICN:77/2010.

Torres, M.D., Raymundo, A., Sousa, I., 2014. Influence of $\mathrm{Na}+, \mathrm{K}+$ and $\mathrm{Ca} 2+$ on mechanical and microstructural properties of gels formed from blends of chestnut and rice flours. Carbohydr. Polym. 102 (1), 30-37. 